\title{
TWO ENGLISH MODIFICATION PATTERNS \\ FOR CHINESE STUDENTS
}

\author{
Yao SHEN \\ University of Michigan
}

$\mathbf{B}_{\text {However, this does not indicate that all the patterns of word }}^{\text {oth Chinese }}$ order in the one language are the same as those of the other language. Neither does it indicate that the two languages do not use one or more patterns that are alike.

The purpose of this article is to show one striking similarity and one striking difference between the English modification patterns and those in Chinese, to point out the importance of the knowledge of such a difference both to the teacher and to the students, and to show how a difficulty resulting from such a difference can be effectively overcome.

The English modification patterns discussed here are limited to those composed of words modifying words that function as nouns. Such modifications fall into two main divisions: pre-modifications and post-modifications. Modifiers which are single words usually precede the word modified: e.g., "I have a red book." Modifiers which are groups of words usually follow the word modified: e.g., "I have a book from China." In Chinese, modifiers of both kinds usually precede the word modified.

In English a single word when used as a modifier usually precedes what is modified. For example: "the English books," "the hard books," "the two books," "the first books," "the boy's books." When such single words are put together, they usually fall into a specific order. For example:

\begin{tabular}{|c|c|c|c|c|c|c|}
\hline the & & & & & & books \\
\hline $\begin{array}{l}\text { the } \\
\text { the } \\
\text { the } \\
\text { the } \\
\text { the }\end{array}$ & boy's & $\begin{array}{l}\text { first } \\
\text { first }\end{array}$ & $\begin{array}{l}\text { two } \\
\text { two } \\
\text { two }\end{array}$ & $\begin{array}{l}\text { hard } \\
\text { hard } \\
\text { hard } \\
\text { hard }\end{array}$ & $\begin{array}{l}\text { English } \\
\text { English } \\
\text { English } \\
\text { English } \\
\text { English }\end{array}$ & $\begin{array}{l}\text { books } \\
\text { books } \\
\text { books } \\
\text { books } \\
\text { books }\end{array}$ \\
\hline the & & & & & & books \\
\hline $\begin{array}{l}\text { the } \\
\text { the } \\
\text { the } \\
\text { the } \\
\text { the }\end{array}$ & $\begin{array}{l}\text { boy's } \\
\text { boy's } \\
\text { boy's } \\
\text { boy's } \\
\text { boy's }\end{array}$ & $\begin{array}{l}\text { first } \\
\text { first } \\
\text { first } \\
\text { first }\end{array}$ & $\begin{array}{l}\text { two } \\
\text { two } \\
\text { two }\end{array}$ & $\begin{array}{l}\text { hard } \\
\text { hard }\end{array}$ & English & $\begin{array}{l}\text { books } \\
\text { books } \\
\text { books } \\
\text { books } \\
\text { books }\end{array}$ \\
\hline
\end{tabular}


Modifiers composed of word groups usually follow the word modified. For example: "the cover of the book," "the boy in section one," "the girl with a beautiful voice."

Those who teach English to students whose native language is Chinese will not have any difficulty in teaching the word order of premodifiers in English. In Chinese, the order of modification of the premodifiers of such a series as given above is the same as that of English. In other words, each of the single word modifiers in the group given falls into the same position in a group of Chinese words. However, in the case of post-modifiers, the problem is entirely different. Teachers will find that many students use as a pre-modifier a construction that should have been a post-modifier in English. They will substitute "the of the book cover" for "the cover of the book," "the in section one boy" for "the boy in section one," "the with a beautiful voice girl" for "the girl with a beautiful voice."

Teachers of English who know the difference between the modification pattern in Chinese and that in English will be able to point out to the students that word-group modifiers that are pre-modifiers in Chinese are post-modifiers in English. By pointing out the difference, the teacher will find it easier to get the problem across to the students. By knowing the difference, the students will find it easier to learn the foreign language.

Before the teacher drills the students orally, it is advisable for him to explain to them the pattern to be practiced. The following method is proposed to handle the question of the teaching of English post-modifiers to Chinese students. The teacher puts the following pattern on the blackboard:

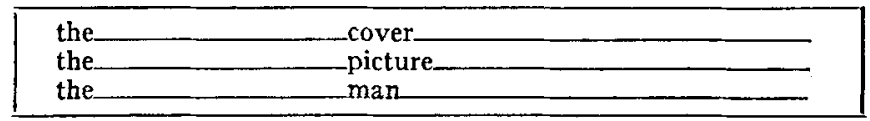

1 "The student standing by the door," "the man who came to dinner," "the time when he arrived," "the pie (that) I made" are some of the examples not treated in this article. Such structures, which usually come later for a student who is learning English, may be practiced with the same method suggested here.

2 Likewise in teaching Chinese to English-speaking students, it is necessary to emphasize the point that modifiers, such as those given, which are postmodifiers in English are pre-modifiers in Chinese. The method suggested in this article may also be used to drill students to use pre-modifiers. 
He shows that there are two positions in English that modifiers may occupy. Whether the modifier occupies the position preceding the noun or following the noun depends upon the kind of modifier. Single words such as paper, beautiful, wise, etc., precede the noun. Thus the English speaking person says: "the paper cover," the beautiful picture," "the wise man." Word groups such as of the book, on the box, at the door, etc., follow the noun. Thus English speaking people say: "the cover of the book," "the picture on the box," "the man at the door." The teacher's examples are limited to this specific difference. After the students have grasped the difference, the teacher goes on with a series of oral drills, for to know how a language operates, and to be able to speak a language are two entirely different things.

The following practices should be given according to the order suggested. Practice 1 aims at getting the students to establish the habit of repeating the post-modifier with the word modified.

Practice 1
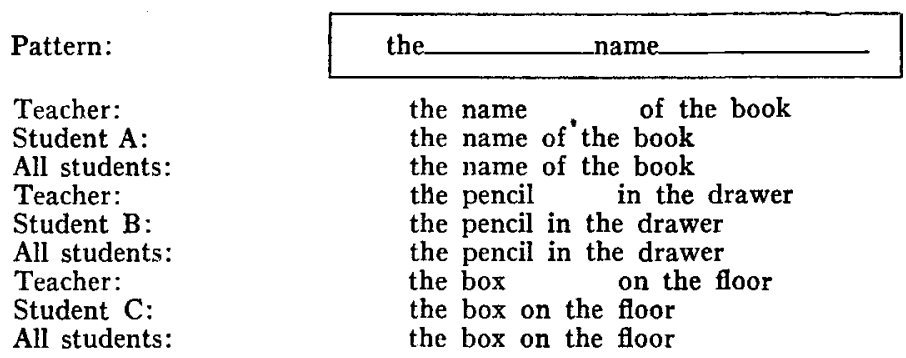

After the students have acquired the desired fluency, the teacher proceeds with the following exercise in which the students have to change the word order.

Practice 2

Pattern:

Teacher:

Student A:

All students:

Teacher:

Student B:

All students:

Teacher:

Student C:

All students:

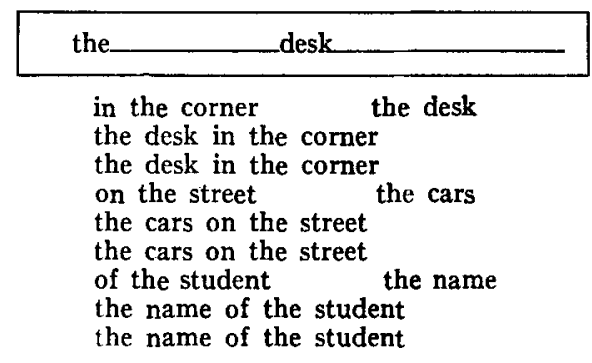


By now the students should have control over the desired word order. The teacher goes on with the following exercise in which the students have to distinguish the positions that different modifiers occupy.

Practice 3

Pattern:

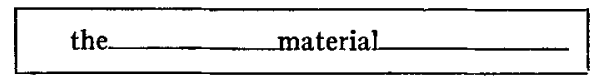

Teacher:

Student A:

All students:

Teacher:

Student B:

All students:

Teacher:

Student C:

All students:

Teacher:

Student D:

All students:

the material red
the red material
the red material
the material
the material of the coat
the material of the coat
in the bottle
the ink in the bottle
the ink in the bottle
the ink
the blue ink
the blue ink

After the students are sure of the position of single word modifiers and that of modifiers composed of a group of words, the teacher repeats the explanation he gave for the different positions of different modifiers. The following exercise is given to test whether the students have grasped the essential point of the whole series of exercises. In the following exercise the students have to distinguish the positions of pre-modifiers and post-modifiers when both are given.

Practice 4

Pattern:

the

books

Teacher:

Student A:

All students:

Teacher:

Student B:

All students:

Teacher:

Student C:

All students:

big on the desk

the big books on the desk the big books on the desk black in the case

the black books in the case the black books in the case at the store interesting the interesting books at the store the interesting books at the store 